\title{
Debendox in early pregnancy and fetal malformation
}

\author{
D M FLEMING, J D E KNOX, D L CROMBIE
}

\begin{abstract}
During the mid-1960s, 22977 pregnant women in Scotland and England were followed up prospectively for the incidence of malformations in their infants evident at birth or within six weeks. During the first 13 weeks of gestation 620 of these women had been prescribed Debendox (dicyclomine-doxylamine-pyridoxine) and 743 other women agents other than Debendox containing pyridoxine.

Of the 620 women given Debendox, 589 (95\%) had a normal outcome of pregnancy, $8(1.3 \%)$ delivered a malformed infant, and $23(3.7 \%)$ had other outcomes. Of the 22357 women who were not given Debendox, 445 $(2.0 \%)$ produced infants with malformation; and the rates for all abnormal outcomes among women given Debendox and those not given the drug were 5.0\% and $5.4 \%$ respectively.

These results support the hypothesis that Debendox is not teratogenic.
\end{abstract}

\section{Introduction}

The report of unusual malformations occurring in the fetuses of women exposed to Debendox (dicyclomine hydrochloride $10 \mathrm{mg}$, doxylamine succinate $10 \mathrm{mg}$, pyridoxine hydrochloride $10 \mathrm{mg}$ ) early in pregnancy ${ }^{1}$ prompted analysis of two prospective studies undertaken by the Royal College of General Practitioners in the mid-1960s. The method and overall results of the English study have been published, ${ }^{2}$ and the method employed in the Scottish study was similar.

\footnotetext{
Birmingham Research Unit of the Royal College of General Practitioners, Birmingham B17 9DB

D M FLEMING, MB, FRCGP, research fellow

D L CROMBIE, MD, FRCGP, director

Scottish General Practitioner Research Unit, University of Dundee, Dundee DD1 4HN

J D E KNOX, MD, FRCGP, director
}

\section{Populations, definition, and results}

We studied 22977 women in whom pregnancy had lasted for 28 weeks or more. Of these women, 14684 were studied in Scotland and 8293 in England. Table I gives the outcomes of the pregnancies in the two series. The incidence of malformation in the defined category was $2.0 \%$ of all births over 28 weeks of gestation and was similar in both studies. The definition of malformation was "a malformation evident at birth or within six weeks in either a live or stillborn infant, which could be diagnosed unequivocally excluding skin malformation." This definition was originally adopted to permit summation of the material obtained in England and France in similar prospective studies and presented in the report of the proceedings of the fourth annual meeting of the French Perinatal Society. ${ }^{3}$ In addition to the $2.0 \%$ embraced by the definition, a further $1.9 \%$ of outcomes were abnormal, including skin malformations and a selection of equivocally diagnosed problems.

TABLE I-Outcome of pregnancies of more than 28 weeks' gestation in Scottish and English series. Number (\%) by outcome category

\begin{tabular}{lccc}
\hline & Scotland & England & Total \\
\hline Normal & $13998(95 \cdot 3)$ & $7740(93 \cdot 3)$ & $21738(94 \cdot 6)$ \\
Malformed (defined in text) & $299(2 \cdot 0)$ & $154(1 \cdot 9)$ & $453(2 \cdot 0)$ \\
$\begin{array}{l}\text { Stillbirths and neonatal deaths } \\
\text { (not malformed) }\end{array}$ & $227(1 \cdot 6)$ & $135(1 \cdot 6)$ & $362(1 \cdot 6)$ \\
Other abnormal outcomes & $160(1 \cdot 1)$ & $264(3 \cdot 2)$ & $424(1.9)$ \\
\hline Total & $14684(100 \cdot 0)$ & $8293(100 \cdot 0)$ & $22977(100 \cdot 0)$ \\
\hline
\end{tabular}

The English figure for other abnormal outcomes (3.2\%) exceeded the Scottish figure $(1 \cdot 1 \%)$ because the follow-up procedure established in the Scottish study resulted in the hardening of diagnostic criteria, with the rejection of some so-called abnormalities and sharper definition of doubtful cases. The rate for non-malformed stillbirths and neonatal deaths was $1.6 \%$ in each study. Table II shows the anatomical distribution of the defined malformations. The small differences between the two studies reflect the different follow-up arrangements.

During the first 13 weeks of pregnancy, dated from the last menstrual period, 620 of the women had been prescribed Debendox (483 in Scotland and 137 in England). Table III shows the outcome of the pregnancies. The 31 abnormal cases are listed in the Appendix, which includes the nature of the malformation and the gestational age at first prescription. There was no particular prevalence of any type of malformation.

Of the 589 women who were issued with a prescription for Debendox 
TABLE II-Anatomical distribution of defined malformations in Scotland and England. Number and rate per (100 000 births)

\begin{tabular}{|c|c|c|c|c|c|c|}
\hline & \multicolumn{2}{|c|}{ Scotland } & \multicolumn{2}{|c|}{ England } & \multicolumn{2}{|c|}{ Total } \\
\hline & No & Rate & No & Rate & No & Rate \\
\hline $\begin{array}{l}\text { Genitourinary } \\
\text { Digestive and respiratory disorders } \\
\text { Cardiovascular } \\
\text { Central nervous system } \\
\text { Special senses } \\
\text { Musculoskeletal } \\
\text { Miscellaneous } \\
\text { Multiple }\end{array}$ & $\begin{array}{r}20 \\
47 \\
20 \\
105 \\
5 \\
75 \\
4 \\
23\end{array}$ & $\begin{array}{r}136 \\
320 \\
136 \\
715 \\
34 \\
511 \\
27 \\
157\end{array}$ & $\begin{array}{r}15 \\
25 \\
25 \\
45 \\
4 \\
21 \\
4 \\
15\end{array}$ & $\begin{array}{r}181 \\
301 \\
301 \\
543 \\
48 \\
253 \\
48 \\
181\end{array}$ & $\begin{array}{r}35 \\
72 \\
45 \\
150 \\
9 \\
96 \\
8 \\
38\end{array}$ & $\begin{array}{r}152 \\
313 \\
196 \\
653 \\
39 \\
418 \\
35 \\
165\end{array}$ \\
\hline Total & 299 & 2036 & 154 & 1857 & 453 & 1972 \\
\hline
\end{tabular}

TABLE III-Outcome of pregnancy after prescription of Debendox during first 13 weeks of pregnancy. Number (\%) of cases

\begin{tabular}{lccc}
\hline & Scotland & England & Total \\
\hline Normal outcome & $458(94 \cdot 8)$ & $131(95 \cdot 6)$ & $589(95 \cdot 0)$ \\
Malformation as defined & $8(1 \cdot 7)$ & 0 & $8(1 \cdot 3)$ \\
Other outcomes & $17(3 \cdot 5)$ & $6(4 \cdot 4)$ & $23(3 \cdot 7)$ \\
\hline Total & $483(100 \cdot 0)$ & $137(100 \cdot 0)$ & $620(100 \cdot 0)$ \\
\hline
\end{tabular}

TABLE IV-Outcome of pregnancy after prescription of drugs containing pyridoxine (Debendox excluded). Number (\%) of recipients

\begin{tabular}{lccc}
\hline & Scotland & England & Total \\
\hline Normal outcome & $378(96 \cdot 2)$ & $328(93 \cdot 7)$ & $706(95 \cdot 0)$ \\
Malformation as defined & $10(2 \cdot 5)$ & $11(3 \cdot 1)$ & $21(2 \cdot 8)$ \\
Other outcomes & $5(1 \cdot 3)$ & $11(3 \cdot 1)$ & $16(2 \cdot 2)$ \\
\hline Total & $393(100 \cdot 0)$ & $350(100 \cdot 0)$ & $743(100 \cdot 0)$ \\
\hline
\end{tabular}

many practices including a total of 458 doctors (290 in Scotland, 168 in England). No assessment was made whether the patient presented the prescription for dispensing or actually took the drug. This was of little relevance, however, since non-compliance was likely to be just as prevalent among those with normal outcomes as among those with abnormal outcomes.

The total use of Debendox was less in the English study than in that reported from Northern Ireland, ${ }^{4}$ where the prescribing rate for Debendox in 1966 was 11.4 prescriptions per 100 live births, rising rapidly over the next five years. An estimate of the equivalent figure based on the English data was 3.0; and, assuming the basis of this estimate applied equally in Scotland, the estimated Scottish equivalent was 5.6. Our figures were derived from women rather than prescriptions and were based on data collected in 1964 and 1965. They reflect the market penetration of Debendox in Britain in the mid-1960s. Debendox accounted for about $10 \%$ of all antiemetics prescribed. The two studies included the ascertainment of self-medication at each consultation. No instance of self-medication with Debendox was identified in a systematic examination of the original records.

If a drug causes fetal malformation it is probable that specific symptom complexes will be identified and, further, that exposure periods of increased risk will be identifiable. In these studies there was neither a concentration of specific abnormalities nor any particular concentration of exposure period among the women with abnormal outcomes. The combination of limbreduction defects and exomphalos was associated with exposure to Debendox at around the sixth week of gestation. ${ }^{1}$ In this study there were two similar cases: in one the mother had received Debendox on the 56th day after the last menstrual period and penicillin for an upper respiratory illness one week before. The other mother had not received any drugs in early pregnancy.

We conclude that Debendox is not specifically incriminated as a cause of fetal malformation. Although there were 31

TABLE V-Outcome of pregnancy by receipt of Debendox in "defined malformations" and "all abnormal outcome" categories

\begin{tabular}{|c|c|c|c|c|c|c|}
\hline & \multicolumn{2}{|c|}{ Scotland } & \multicolumn{2}{|c|}{ England } & \multicolumn{2}{|c|}{ Total } \\
\hline & Recipients & Non-recipients & Recipients & Non-recipients & Recipients & Non-recipients \\
\hline $\begin{array}{l}\text { Defined malformations } \\
\text { All other outcomes }\end{array}$ & $\begin{array}{r}8 \\
475\end{array}$ & $\begin{array}{r}291 \\
13910\end{array}$ & $\begin{array}{r}0 \\
137\end{array}$ & $\begin{array}{r}154 \\
8002\end{array}$ & $\begin{array}{r}8 \\
612\end{array}$ & $\begin{array}{r}445 \\
21912\end{array}$ \\
\hline $\begin{array}{l}\text { Total } \\
\% \text { Malformed }\end{array}$ & $\begin{array}{l}483 \\
1 \cdot 7\end{array}$ & $\begin{array}{c}14201 \\
2 \cdot 0\end{array}$ & 137 & $\begin{array}{c}8156 \\
1.9\end{array}$ & $\begin{array}{l}620 \\
1 \cdot 3\end{array}$ & $\begin{array}{l}22357 \\
2 \cdot 0\end{array}$ \\
\hline $\begin{array}{l}\text { All abnormal outcomes } \\
\text { Normal outcome }\end{array}$ & $\begin{array}{r}25 \\
458\end{array}$ & $\begin{array}{r}661 \\
13540\end{array}$ & $\begin{array}{r}6 \\
131\end{array}$ & $\begin{array}{r}547 \\
7609\end{array}$ & $\begin{array}{r}31 \\
589\end{array}$ & $\begin{array}{rl}1 & 208 \\
21 & 149\end{array}$ \\
\hline $\begin{array}{l}\text { Total } \\
\% \text { Abnormal }\end{array}$ & $\begin{array}{l}483 \\
5 \cdot 2\end{array}$ & $\begin{array}{c}14201 \\
4 \cdot 7\end{array}$ & $\begin{array}{l}137 \\
4 \cdot 4\end{array}$ & $\begin{array}{c}8156 \\
6 \cdot 7\end{array}$ & $\begin{array}{l}620 \\
5 \cdot 0\end{array}$ & $\begin{array}{c}22357 \\
5 \cdot 4\end{array}$ \\
\hline
\end{tabular}

and had a normal outcome, 215 (165 in Scotland, 50 in England) received the prescription in the first eight weeks (56 days) of pregnancy: the proportions of such women were similar in the two studies $36 \%$ and $38 \%$ respectively). Of the 31 recipients having an abnormal outcome, $12(39 \%)$ received the prescription in the first eight weeks. About half of all women issued with prescriptions for Debendox received them during the seventh, eighth, and ninth weeks.

Pyridoxine is a constituent of Debendox and of several other antiemetic preparations. Table IV shows the combined results for these drugs. Of the 706 women with a normal outcome, $279(40 \%)$ received the prescription in the first eight weeks; and of the 37 with an abnormal outcome, $11(30 \%)$ were given a prescription within the first eight weeks.

\section{Discussion}

These results stem from prospective studies in which associations between drugs and malformation were being sought among abnormal outcomes, it is difficult to believe that there could have been 589 normal outcomes if Debendox had any appreciable teratogenic potential. Furthermore, in each locality the proportion of outcomes with defined malformations referable to Debendox recipients was less than the corresponding proportion for non-recipients, though none of the differences between proportions referable to recipients and non-recipients were statistically significant (table V). The relative risk of occurrence of defined malformation among recipients in the entire study was 0.644 , and the $95 \%$ confidence limits for this value are approximately 0.32 to 1.30 .

In presenting this conclusion we add to the evidence of Milkovich and Van den Berg, ${ }^{5}$ who reported a prospective survey in which there was no association between the use of Bendectin (similar in composition to Debendox) in pregnancy and subsequent outcome. This view was supported by Smithells and Sheppard, ${ }^{6}$ who used general-practitioner prescription forms as a starting point. 
We thank $\mathrm{K} \mathrm{W}$ Cross, of the department of social medicine at the University of Birmingham, for help in considering the statistical implications, and the doctors who co-operated in gathering the data. We also acknowledge the valued contributions of Mrs B Hogg (Dundee) and Mrs J Dainty (Birmingham).

\section{Appendix}

Abnormal outcomes after prescription of Debendox. (Figures in parentheses show gestational age (days) at issue of first prescription (if before day 56))

In Scotland defined malformations were multiple anomalies (heart and kidney); Klippel-Feil syndrome; right leg a stump and exomphalos (56); hiatus hernia; exomphalos; diaphragmatic hernia; webbing of toes; and mongolism (33). Other abnormal outcomes were bilateral slight pes equinovarus (56); minor talipes (22); systolic murmur not fully diagnosed (45); undescended testes (53); systolic murmur, mitral area; bilateral congenital dislocation of hips; undescended testes (47); birthmark on right leg; subluxation of right hip; two cases of macerated stillbirth, cause not known; fresh stillbirth (cord round neck); stillbirth (antepartum haemorrhage) (50); intrauterine death (rhesus problem) (45); stillbirth (cord round neck); neonatal death at one month (bronchopneumonia); and neonatal death on third day $(2160 \mathrm{~g})$.

In England there were no defined malformations; other abnormalities were congenital heart disease (not fully diagnosed) (46); symptoms of hiatus hernia (51); possible mongolism; congenital heart disease (not fully diagnosed); pyloric stenosis; and stillbirth (less than $450 \mathrm{~g}$ ).

\section{References}

1 Donnai D, Harris R. Unusual fetal malformations in early pregnancy. Br Med f 1978; :691-2.

2 Birmingham Research Unit of the Royal College of General Practitioners. Morbidity and drugs in pregnancy. $\mathcal{F} R$ Coll Gen Pract $1975 ; 25: 631-45$.

${ }^{3}$ Crombie DL, Fleming DM. Aspects of prescribing during pregnancy. Proceedings of the Fourth National Congress of the French Perinatal Medical Society. Paris: Dubois and Renaud Librairie Arnette, 1975: 117-27.

4 Harron DWG, Griffiths K, Shanks RG. Debendox and congenital malformation in Northern Ireland. $\mathrm{Br}$ Med $\mathcal{f} 1980 ; 281: 1379-81$.

${ }^{5}$ Milkovich L, Van den Berg BJ. An evaluation of the teratogenicity of certain anti nauseant drugs. Am F Obstet Gynecol 1976;125:244-8.

6 Smithells RW, Sheppard S. Teratogenicity testing in humans: a method demonstrating safety of Bendectin. Teratology 1978;17:31-5.

(Accepted 12 May 1981)

\title{
Yersinia enterocolitica arthritis in southern Sweden: a four-year follow-up study
}

\author{
LUDMILA MARSAL，STEN WINBLAD，FRANK A WOLLHEIM
}

\begin{abstract}
Thirty-eight cases of suspected yersinia arthritis occurring in southern Sweden in 1975-6 were reviewed four to five years later. In 31 cases the diagnosis was confirmed. At follow-up three of the patients had definite ankylosing spondylitis, three radiologically confirmed sacroiliitis, three extensor tenosynovitis, five isolated articular joint disease, and $\mathbf{1 0}$ localised arthralgias; one patient had developed seropositive rheumatoid arthritis. Only six of the 31 patients were free of joint symptoms.

These results suggest that although the acute symptoms of yersinia arthritis disappear within 12 months, the long-term prognosis may be less favourable than previously thought.
\end{abstract}

\section{Introduction}

Reactive arthritis after infection with Yersinia enterocolitica is well recognised in some parts of the world, ${ }^{1-9}$ and the prognosis is generally assumed to be favourable. An association with HLA-B27,10-14 and evidence of transition into rheumatoid arthritis have been reported, ${ }^{3}{ }^{4}{ }^{6}$ but few systematic long-term follow-up studies have been published. We have therefore studied the outcome in a consecutive group of patients four years after acute yersinia arthritis. A surprisingly high incidence of joint symptoms was encountered.

Department of Medicine, Division of Rheumatology, and Department of Bacteriology, Malmö General Hospital, University of Lund, Malmö, Sweden

LUDMILA MARSAL, MD, registrar in rheumatology

STEN WINBLAD, MD, emeritus professor of bacteriology

FRANK A WOLLHEIM, MD, senior lecturer in rheumatology

\section{Patients and methods}

We reviewed 45 consecutive patients in whom during 1975-6 suspected reactive arthritis had been diagnosed and tests on sera had yielded positive agglutinin titres against $Y$ enterocolitica type 3 . Of these patients, 38 were traced and re-examined clinically. $X$-ray pictures were taken from painful joints. Blood was analysed for haemoglobin concentration, erythrocyte sedimentation rate, liver enzyme activities, and serum creatinine concentration. Urine analysis was performed. In addition, a plasma sample was analysed for concentrations of albumin, fibrinogen, $\alpha_{1}$-antitrypsin, orosomucoid, haptoglobin, caeruloplasmin, IgG, IgA, IgM, C3, and C4.

\section{Results}

\section{INITIAL DISEASE}

In 31 of the 38 patients the diagnosis of yersinia arthritis was confirmed by a history of unequivocal acute arthritis documented by their doctors and concomitant agglutination test titres against $Y$ enterocolitica type 3 of 160 or more. In the remaining seven patients yersinia arthritis could not be confirmed. The age range was 26-76 years and the mean 48 years. Nineteen of the patients were women and 12 men (table I). In 20 cases the onset of the disease occurred during September to December (table II). The affected joints were knees (19 instances); ankles (12); fingers (15); wrists (nine); toes (nine); shoulders (four); elbows (four); and low back (four). Over four joints were affected in 13 patients. The acute joint symptoms lasted from six weeks to 12 months.

\section{FOLLOW-UP INVESTIGATION}

Of the six patients who were free of joint symptoms and had normal physical findings, one (case 27) developed an atrioventricular conduction block, probably after yersinia myocarditis. In the remaining 25 patients joint complaints and findings varied (table I). A 